\title{
PENINGKATAN KETERAMPILAN DASAR LABORATORIUM UNTUK MAHASISWA DALAM MENYONGSONG ERA INDUSTRI 4.0
}

\author{
Maria Ulfa ${ }^{1}$, I Made Sudarma ${ }^{1}$, Ni Komang Tri Dharmayani ${ }^{1}$, Sudirman ${ }^{1}$, Emmy Yuanita ${ }^{1}$ \\ 1 Program studi kimia, Fakultas MIPA, Universitas Mataram \\ *Co-Author : emmy_yuanita@unram.ac.id
}

\begin{abstract}
ABSTRAK. Sebagai salah satu universitas negeri di Indonesia, Universitas Mataram, khususnya program studi kimia yang berada di bawah FMIPA mencoba melakukan usaha perbaikan kualitas pendidikian sehingga diharapkan mampu mencetak lulusan yang siap berkompetisi di era industri 4.0. Upaya yang dilakukan adalah dengan meningkatkan keterampilan dalam melakukan praktik atau penelitian bagi mahasiswa di program studi kimia FMIPA Universitas Mataram. Kegiatan ini dilaksanakan melalui program kegiatan Pengabdian masyarakat. Kegiatan ini bertujuan untuk meningkatkan keterampilan dan pengetahuan mahasiswa, khususnya pengembangan pembelajaran berbasis ekperimen atau praktikum. Pelatihan dilaksanakan dalam bentuk sosialisasi dan workshop oleh kelompok dosen di bidang Kimia Organik berkolaborasi dengan bidang Kimia Fisika FMIPA Universitas Mataram. Kegiatan ini mampu meningkatkan pengetahuan dan keterampilan serta perubahan sikap mahasiswa terutama dalam mengoperasikan peralatan laboratorium; penanganan bahan kimia, serta beberapa teknik-teknik eksperimental di laboratorium. Hasil evaluasi kegiatan menunjukkan peningkatan kompetensi mahasiswa yang cukup signifikan dibandingkan sebelum mendapatkan pelatihan. Kegiatan ini perlu terus dilakukan secara berkala dengan beberapa perbaikan seperti rancangan perencanaan, implementasi pelaksanaan dan evaluasi yang tepat dalam penyelenggaraan kegiatan untuk mencapain sasaran kegiatan.
\end{abstract}

Kata Kunci: Era Industri 4.0, keterampilan laboratorium, kompetisi, penelitian, praktik.

ABSTRACT. As one of the state universities in Indonesia, the University of Mataram, especially the chemical study program under FMIPA, is trying to improve the quality of education so that it is expected to be able to produce graduates who are ready to compete in the industrial era 4.0. Efforts are being made to improve skills in conducting practice or research for students in the chemical study program at the University of Mataram's Mathematics and Natural Sciences. This activity is carried out through a community service program. This activity aims to improve the skills and knowledge of students, especially the development of experimental or practicum-based learning. The training was held in the form of socialization and workshops by a group of lecturers in the field of Organic Chemistry in collaboration with the field of Physics Chemistry, FMIPA, University of Mataram. This activity is able to increase knowledge and skills as well as changes in student attitudes especially in operating laboratory equipment; handling chemicals, as well as several experimental techniques in the laboratory. The results of the evaluation of activities showed a significant increase in student competence compared to before getting training. This activity needs to be carried out regularly with a number of improvements such as design planning, implementation, implementation and evaluation in the implementation of activities to achieve the activity objectives.

Keyword: Industrial Era 4.0, laboratory skills, competition, research, practice. 


\section{PENDAHULUAN}

Pesatnya perkembangan teknologi yang terjadi saat ini yaitu pada era revolusi industri 4.0 menuntut perguruan tinggi di Indonesia untuk dapat mengantisipasinya. Perkembangan dan kompetisi tidak hanya terjadi di dunia bisnis, akan tetapi juga berdampak di bidang pendidikan. Perguruan tinggi dituntut mencetak SDM dengan kualitas yang dapat berkompetisi secara global dalam segala hal. Tantangan yang kita hadapi adalah bagaimana mempersiapkan dan memetakan angkatan kerja dari lulusan pendidikan yang benar-benar siap kerja, yang dengan kata lain profesional sesuai dengan bidang keahlianya, dalam menghadapi revolusi industri 4.0.

Universitas Mataram sebagai salah satu universitas negeri di Indonesia, khususnya program studi kimia yang berada di bawah FMIPA mencoba melakukan usaha perbaikan kualitas pendidikian sehingga diharapkan mampu mencetak lulusan yang siap berkompetisi di era industri 4.0. IImu kimia sendiri merupakan salah satu bidang ilmu yang menerapkan metode pembelajaran pada dua hal yaitu teori dan praktikum. Kedua hal ini saling terikat dan tidak bisa dipisahkan. Eksperimen atau praktik akan menjelaskan dan menguji kebenaran teori yang dipelajari. Atas dasar tersebut, penting bagi setiap mahasiswa yang mempelajari kimia memiliki skill atau keterampilan dasar dalam hal penangan peralatan dan bahan kimia serta teknik-teknik praktik atau penelitian di laboratorium.

Berdasarkan pemaparan tersebut, upaya yang dapat dilakukan adalah dengan meningkatkan kompetensi mahasiswa terutama pemahaman teori, perubahan sikap dalam bekerja dan keterampilan dalam melakukan praktik atau penelitian. Untuk itu diperlukan peran aktif dari lembaga pendidikan tinggi sebagai salah satu bentuk Tri Darma Perguruan Tinggi. Pengabdian dapat dilakukan untuk membantu pemerintah secara umum dalam menghasilkan lulusan berkualitas profesional dan berdaya saing sehingga mampu menghasilkan sumber daya manusia yang berkualitas juga.

Program Studi Kimia FMIPA Universitas Mataram sebagai satu-satunya program studi kimia murni yang ada di wilayah Nusa Tenggara Barat mempunyai visi di tahun 2020 sebagai pusat kajian ilmu kimia di kawasan Indonesia timur yang berbasis sumber daya lokal. Untuk mendukung perwujudan visi tersebut tentunya perlu dilakukan berbagai kegiatan baik dalam bidang penelitian ataupun pengabdian. Dalam bidang penelitian dilakukan dengan cara melakukan penelitian yang inovatif dan kreatif untuk pengembangan ilmu kimia dan terapannya dalam mengeksplorasi sumber daya alam lokal. Selanjutnya untuk bidang pengabdian dapat dilakukan dengan menyelenggarakan layanan kepada masyarakat secara profesional dalam bidang ilmu kimia. Pengabdian masyarakat yang telah dilakukan program studi kimia adalah dalam bentuk sosialisasi dan workshop dengan pemberian teori dan praktik secara demo maupun mandiri.

\section{METODE PELAKSAAN PENGABDIAN}

Metode yang digunakan untuk pelaksanaan pengabdian masyarakat adalah melalui pendampingan oleh dosen dengan metode ceramah, praktik, dan diskusi. Gabungan dari ketiga metode tersebut diharapkan meningkatkan pemahaman dan keterampilan mahasiswa dalam melakukan praktikum dan penelitian di laboratorium kimia. Dengan demikian secara tidak langsung proses pembelajaran dan penelitian akan lebih efektif dan efisien. Kompetensi mahasiswa program 
studi kimia FMIPA Universitas Mataram diharapkan meningkat dan resiko kecelakaan di laboratorium dapat dikurangi.

Untuk mengetahui keberhasilan program pengabdian kepada masyarakat dilakukan evaluasi terhadap tingkat pemahaman dan penguasaan materi pelatihan para peserta mencakup kepemahaman terhadap penggunaan alat di laboratorium, MSDS bahan, dan beberapa teknik sederhana. Evaluasi dilaksanakan di akhir kegiatan dengan tujuan melihat tingkat pemahaman dan keterampilan peserta pelatihan serta sebagai bahan rujukan untuk pelaksanaan kegiatan yang sama di kurun waktu yang telah disepakati.

\section{HASIL DAN PEMBAHASAN}

Pelatihan merupakan suatu bentuk pembelajaran yang bermuara pada perubahan, sehingga peran seorang pelatih adalah bertanggung jawab terhadap terjadinya perubahan sikap dan perilaku peserta pelatihan. Dalam proses pelatihan pada kegiatan ini memuat prinsip pembelajaran, yaitu: memotivasi peserta, keterlibatan peserta secara aktif, materi pelatihan relevan dengan tugas, penyampaian materi yang sistematis, adanya umpan balik, dan ada perbaikan setelah pelatihan setelah dievaluasi.

Pelatihan pada kegiatan pengabdian ini difokuskan untuk mahasiswa semester 6 program studi kimia FMIPA UNRAM yang telah mempunyai pengalaman sebagai asisten dan dalam tahap melakukan penelitian pendahuluan untuk tugas akhir. Pelatihan dilaksanakan selama 2 (dua) hari dengan rincian agenda yaitu satu hari pembekalan terkait dengan penggunaan peralatan (laboratorium) sederhana; MSDS bahan kimia dan beberapa teknik dasar yang harus dikuasai mahasiswa seperti metode pemisahan (contoh : ektraksi, kromatografi). Hari berikutnya adalah praktik yang dilaksanakan secara terbimbing di laboratorium kimia dasar FMIPA UNRAM.

Tabel 1 Kondisi pelaksaaan pelatihan peningkatan kompetensi mahasiswa

\begin{tabular}{|c|c|c|c|c|}
\hline No & Aspek & Kriteria Penilaian & Hasil Evaluasi & Taksiran \\
\hline 1 & $\begin{array}{l}\text { Kesesuaian } \\
\text { dengan rencana } \\
\text { kegiatan }\end{array}$ & $\begin{array}{l}\text { Sesuai dengan } \\
\text { rencana yang telah } \\
\text { disusun }\end{array}$ & $\begin{array}{l}\text { Pelatihan telah sesuai } \\
\text { dengan rencana kegiatan di } \\
\text { antar semester }\end{array}$ & Efektif \\
\hline 2 & $\begin{array}{l}\text { Ketersediaan } \\
\text { dana }\end{array}$ & $\begin{array}{l}\text { Tersedia dana yang } \\
\text { cukup }\end{array}$ & $\begin{array}{l}\text { Dana pelatihan masih } \\
\text { swadaya }\end{array}$ & $\begin{array}{l}\text { Belum } \\
\text { efektif }\end{array}$ \\
\hline 3 & $\begin{array}{l}\text { Kehadiran } \\
\text { peserta }\end{array}$ & $\begin{array}{l}\text { Peserta yang hadir } \\
\text { lebih dari } 75 \%\end{array}$ & $\begin{array}{l}\text { Seluruh peserta yang } \\
\text { mendaftar hadiri }\end{array}$ & Efektif \\
\hline 4 & Keaktifan peserta & $\begin{array}{l}\text { Peran aktif dalam } \\
\text { mengikuti kegiatan }\end{array}$ & $\begin{array}{l}\text { Seluruh peserta aktif dalam } \\
\text { mengikuti pelatihan }\end{array}$ & Efektif \\
\hline 5 & Nara Sumber & $\begin{array}{l}\text { Nara sumber } \\
\text { memiliki kompetensi } \\
\text { yang disyaratkan }\end{array}$ & $\begin{array}{l}\text { Persyaratan kompetensi } \\
\text { instruktur tidak dirumuskan } \\
\text { sedara tertulis }\end{array}$ & $\begin{array}{l}\text { Belum } \\
\text { efektif }\end{array}$ \\
\hline
\end{tabular}


Berdasarkan hasil pada Tabel 1. kondisi pelaksanaan pelatihan secara umum telah berjalan cukup efektif. Kesesuaian jadwal kegiatan, kehadiran dan keaktifan peserta sesuai dengan kriteria penilaian. Pendanaan kegiatan sangat perlu dianggarkan demi mencapai visi dan misi yang dicanangkan program studi kimia khususnya. Keaktifan peserta dalam memahami teori dibarengi dengan peningkatan keterampilan peserta dalam praktik di laboratorium. Peningkatan kompetensi ini diharapkan akan membawa dampak pada kualitas peserta sebagai asisten praktikum yang akan membimbing mahasiswa praktikum serta dalam bekerja sebagai peneliti pemula.

Evaluasi kegiatan pelatihan dilakukan di akhir kegiatan untuk mendapatkan data informasi yang benar mengenai pelaksanaan kegiatan sehingga penyelenggaraan pelatihan dapat direncanakan keberlanjutannya.

Pemberian keterampilan laboratorium pada peserta pelatihan akan menghasilkan suatu kebiasaan berpikir dan strategi kognitif untuk berpikir. Peningkatan keterampilan laboratorium mahasiswa dapat berjalan dengan baik didukung oleh beberapa faktor di antaranya adalah : kesiapan dosen dalam membagi pengalaman dan membimbing mahasiswa pada saat praktikum atau penelitian; ketersediaan peralatan dan bahan yang dibutuhkan relative memadai dalam menjalankan praktikum atau penelitian.

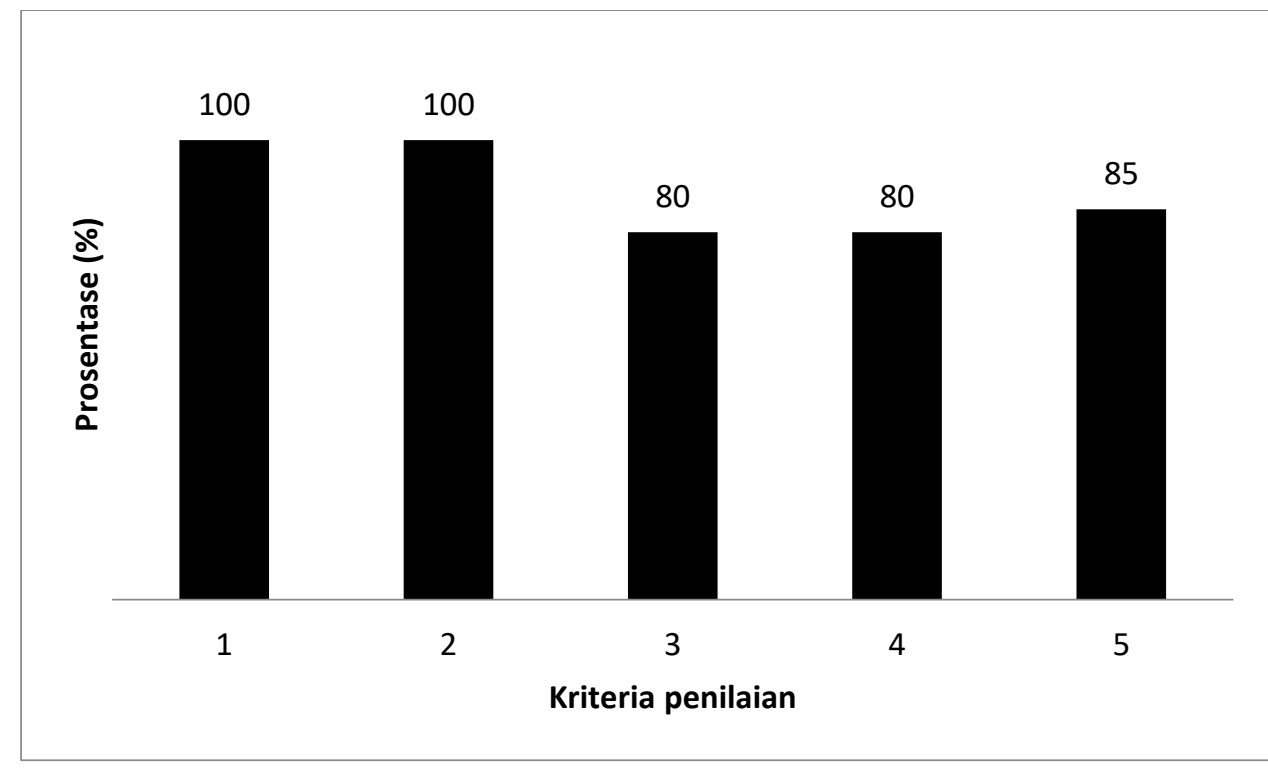

Gambar 1. Profil kompetensi peserta pelatihan

Berdasarkan gambar 1, peningkatan kompetensi peserta berdasarkan hasil evaluasi sesuai kriteria penilaian menunjukkan bahwa ada perubahan pengetahuan, sikap dan keterampilan peserta pelatihan. Perubahan sikap peserta dalam mengikuti pelatihan sangat aktif dan antusias 
dikarenakan pemahaman mereka akan tujuan pelatihan (1) mencapai 100\%. Pemahaman terhadap tugas sebagai asisten maupun pribadi di laboratorium (2) mencapai $100 \%$, hal ini menunjukkan mahasiswa siap bekerja sebagai asisten maupun peneliti pemula dengan pengelolaan manajemen yang lebih bagus dibandingkan sebelum melakukan pelatihan. Kemampuan peserta dalam memahami materi pelatihan (3) kemampuan peserta dalam merangkai dan mengoperasikan peralatan (4) lebih dari 75\%; peningkatan pemahaman dan keterampilan laboratorium akan prinsip teknik-teknik dasar dan analisis (5) sesuai dengan materi pelatihan lebih dari $75 \%$.

\section{KESIMPULAN}

1. Kegiatan pelatihan peningkatan keterampilan dasar mahasiswa di Laboratorium Kimia Dasar FMIPA Universitas Mataram cukup efektif ditinjau berdasarkan kriteria yang ditetapkan.

2. Kompetensi mahasiswa dalam memahami dan menguasai materi serta teknik-teknik dasar di laboratorium meningkat lebih dari $75 \%$ dibandingkan sebelum mendapatkan pelatihan

\section{REFERENSI}

Day dan Underwood, 2002. Analisis Kimia Kuantitatif. Jakarta: Erlangga.

Ira. (2018, 1 30). Ristekdikti: Era Revolusi Industri 4.0 Saatnya Generasi Milenial Menjadi Dosen Masa Depan. Diambil kembali dari Ristekdikti: htttp://www.sumberdaya.ristekdikti.go.id/era-revolusi-Industri-4-0-saatnya-generasimilenial-menjadi-dosen-masa-depan

Koesmadji, W. 2000. Teknik Laboratorium Kimia. Jakarta: FMIPA UI.

Prasetyo, H. 2018. Industri 4.0: Telaah Klasifikasi Aspek Dan Arah Perkembangan Riset. UNDIP: Jurnal Teknik Industri; Vol. 13 (1).

Soemanto, I. 2007. Kesehatan Dan Keselamatan Kerja dalam Laboratorium Kimia. ISBN: 978-979-16832-1-0.

Widarto. 2005. Bahan Praktikum dan Penyimpanannya. Yogyakarta: UNY. 